\title{
$\boldsymbol{\nabla}$ Artikkeli
}

\section{Tiedon markkinoilla - pörssiyhtiön tuloksen hallintaa viestinnän keinoin}

\begin{abstract}
Pörssiyhtiöt suunnittelevat liiketoiminnan tulosta ja siitä tiedottamista tarkoituksena välittää positiivinen kuva yhtiön toiminnasta ja talousjohdon pätevyydestä. IImiö tunnetaan laskentatoimen alueella tuloksen hallintana (earnings management; earnings game). Aiempi tutkimus liiketaloustieteissä ja yritysviestinnän alueella on keskittynyt määrällisiin tutkimusmenetelmiin ja haastatteluihin. Tässä artikkelissa tutkitaan genreen perustuvin tekstianalyysin menetelmin tuloksenhallintaa suomalaisessa sijoittajaviestinnässä: miten ilmiö näkyy diskursiivisesti ja kielellisesti tilinpäätöstiedotteissa? Tutkimus tuo lisää tietoa tuloksenhallinnan viestinnällisistä keinoista ja ilmiön yhteiskunnallisesta merkityksestä ja osoittaa, että tiettyjen kielellisten ja rakenteellisten valintojen kautta taloushallinnon ja viestinnän ammattikäytännöt kohtaavat pörssitiedotteiden säännellyssä tekstilajissa. Samalla eri tekstilajien piirteet sekoittuvat niin, että pörssiyhtiöiden vertailu sijoituskohteen näkökulmasta tekstien pohjalta vaikeutuu. Tutkimusaineistona on Suomessa listattujen eri toimialojen yhtiöiden tilinpäätöstiedotteita keväältä 2006.
\end{abstract}

AVAINSANAT: genre, profilointi, sijoittajaviestintä, talousjournalismi, tekstilaji, tuloksenhallinta, ulkoinen yhteisöviestintä

$\mathrm{L}$

istatut yhtiöt eli pörssiyhtiöt ovat talouselämässä erityistarkkailussa: sekä niiden toiminta että siitä viestiminen ovat säänneltyjä, ja media on enenevässä määrin kiinnostunut uutisoimaan taloudesta joko sijoittajien tai ekonomistien näkökulmasta (esim. Hirsto \& Moisander 2010, 123). Taloudesta uutisoimisella on pitkät perinteet. Toimittajien kiinnostus osakkeita ja pääomamarkkinoita kohtaan syntyi Isossa-Britanniassa jo 1800-luvulla (Uskali 2005, 27). Talousuutiset ovat aina kiinnostaneet uutisten lukijoita jopa siinä määrin, että esimerkiksi mediakonserni Reutersin kannattavuus oli talousjournalismin varassa 1950-luvulla. Suomessa talousjournalismin erikoisalueen pörssijournalismin nousu ajoittui 1980-luvulle, jolloin rahamarkkinat vapautuivat. (Uskali 2005, 40-41.) Pörssiyhtiöiden vuosi- ja osavuositulos ovat olleet keskeisiä uutisaiheita viime vuosikymmeninä (Luoma-aho ym. 2011, 45), erityisesti kun osakkeisiin sijoittamisesta on tullut jokamiehen harrastus (Carroll 2011, 3; Uskali 2005). Sinänsä kaikki pörssiyhtiön tekemiset näyttävät olevan uutisen arvoi- 
sia (Luoma-aho ym. 2011, 55), ja pääsy median agendalle palvelee usein pörssiyhtiön tavoitteita ja vaikuttaa julkisen imagon kautta maineeseen (emt., 42).

Taloustiedolla on ollut arvonsa jo satoja vuosia, ja talouden teema on levinnyt muihinkin kuin talousuutisiin (Uskali 2005, 37). Pörssiyhtiö toimii tiedon markkinoilla, joilla yhtiön arvo määräytyy kaiken markkinoilla olevan tiedon perusteella. Taloustiedon välittämiseen liittyy niin sanottu tuloksenhallinnan ilmiö, jota kohtaan monet tieteenalat ovat osoittaneet kiinnostusta. Erityisesti laskentatoimen tutkimuksissa näytetään olevan yhtä mieltä siitä, että taloudellinen tulos on tulosraportoinnin kriittisin informaatio. Sekä tiedolla kuluneen vuoden toiminnasta että tulevaisuudennäkymistä on merkitystä sijoituspäätöksissä, mutta myös yhtiön kyky selviytyä vastuistaan, mahdollisuudet saada rahoitusta edullisesti ja johdon palkitsemiskäytännöt kannustavat pörssiyhtiöitä suunnittelemaan tilinpäätöstä, jotta tulos näyttäisi mahdollisimman hyvältä (esim. Degeorge ym. 1999, 29; Sundgren 2007). Taloustoimittaja Päivi Isotaluksen mukaan ulkomaisten skandaaliyhtiöiden, kuten Enronin, johto pyrki 1980- ja 2000-luvuilla keinoja kaihtamatta saamaan tilinpäätöksensä näyttämään hyvältä (Uskali 2005, 48).

Laskentatoimen tutkimuksissa tuloksenhallinta (earnings game tai earnings management) tarkoittaa toiminnan tuloksen suunnittelua itse tilinpäätöstä laadittaessa (esim. Kasanen ym. 1996; Degeorge ym. 1999; Sundgren 2007; Hens 2008). Ilmiötä on tutkittu erityisesti pörssiyhtiöiden osavuosiraportointiin liittyvänä, lyhyen perspektiivin edun tavoitteluna. Thorsten Hensin mukaan sijoittajien odotusten täyttämisen ja yllätysten välttämisen vuoksi johto pyrkii manipuloimaan tulosta tietyllä aikavälillä (Hens 2008; myös Graham ym. 2005; Sundgren 2007). Tuloksenhallintaa tapahtuu sekä lukujen tasolla tilinpäätöstä muotoiltaessa että tekstin tasolla siitä viestittäessä. Ulkoisen yhteisöviestinnän, erityisesti talouselämän viestinnän, tutkijana minua kiinnostaa se, miten tilinpäätöstiedote, sijoittajaviestinnän yksi tekstilaji, toimii osana yrityksen tiedonvälitystä ja tuloksenhallintaa. Yleisemmin kiinnostuksen kohteena on siis se, miten asioita saadaan tehdyksi tilanteisiin vakiintuneiden viestintäkäytänteiden ja tekstilajien avulla (esim. Swales 1990; Fairclough 1992; Martin \& Rose 2003; Bhatia 2004). Tutkimus pörssiyhtiöiden viestinnästä onkin kaivannut merkityksen tulkintaan syvemmälle menevää otetta. Esimerkiksi Henk Pander Maat (2007, 94; myös Graham ym. 2005) on päätellyt, että pörssiyhtiöiden viestinnän tutkimukselle ovat hyödyksi tyylin analyysi ja tekstilajivertailut, jotta saadaan laajempi käsitys kielenkäytön kulttuurista.

Tässä artikkelissa jatkan laskentatoimen alueella tehtyä tuloksen hallinnan tutkimusta genreanalyysin menetelmin (ks. Bhatia 2004, 2010). Aineisto koostuu suomalaisten pörssiyhtiöiden tilinpäätöstiedotteista. Genrenalyysi kohdistuu tekstin resursseihin, esimerkiksi kielellisiin piirteisiin ja kieliopillisiin resursseihin, diskurssimalleihin, retoriseen strategiaan ja diskurssienvälisyyteen. Kaikkia tekstiresursseja analysoidaan genren konventioiden ja käytänteiden kontekstissa ( Bhatia 2004, 161-165.) Genreanalyysi sisältää lähtökohtaisesti myös diskurssien tulkintaa: instituutioiden ja organisaatioiden rakennusaineina ovat erilaiset ihmisten kohtaamiset, viestinnän toteutumat, esimerkiksi kirjoitetut tekstit (esim. Fairclough 1992; Bhatia 2004; Kunelius 1996, 391). Lisäksi kulttuuriset, myös ammattikulttuuriset, käytänteet vaikuttavat nimenomaan diskursseihin (Bhatia 2010; Kunelius 1996, 391). Vijay K. Bhatian mukaan (2004) kirjoi- 
tettu diskurssi esiintyy neljässä tilassa: etnografisessa, tekstuaalisessa, sosio-kognitiivisessa ja sosiaalisessa (emt., 163).

Genreanalyysi nojaa funktionaaliseen kielikäsitykseen (Halliday 1994), ja sillä on sukulaissuhde uuteen retoriikkaan. Institutionaalisessa kontekstissa vuorovaikutusta ohjaa halu vakuuttaa yleisö ja saada se sitoutumaan (esim. Jokinen 1999, 46; Perelman 1996). Tässä tutkimuksessa kiinnitänkin huomiota erityisesti siihen, miten tulosjulkistuksessa tärkeä tiedotteen alkuosa muotoillaan. Tekstin alun perusteella tehdään muutamassa sekunnissa ensimmäiset kaupat. Artikkelini tutkimuskysymykset ovat seuraavat: 1) miten tuloksenhallintaa toteutetaan pörssiyhtiön vuosituloksen julkistuksen yhteydessä tilinpäätöstiedotteella ja 2) miten taloushallinnon ja viestinnän ammattikäytännöt ja -kulttuurit kohtaavat tilinpäätöstiedotteen säännellyssä tekstilajissa.

Tutkimukseni on tekstin kontekstia ja yhteisöllisyyttä korostavaa genre- eli tekstilajitutkimusta. Esimerkiksi mediatutkimuksessa on tekstien piirteiden luokittelusta siirrytty jo 1970-luvulla kulttuuristen rakenteiden analyysiin ajatuksena muun muassa se, että tekstilaji on konventioihin ja odotuksiin pohjautuva kommunikatiivinen sopimus sekä dynaaminen ja merkityksenantoa aktiivisesti järjestävä ilmiö (Ridell 2006, $188,191)$. Eija Ventola $(2006,104)$ on määritellyt tekstilajin yleisesti niin, että se on sosiaalisen toiminnan laji ja se tunnistetaan siitä, että samanlaisessa tilanteessa tuotetut tekstit muistuttavat toisiaan. Lisäksi niissä toiminta etenee kulttuuristen odotusten mukaisesti. Bhatian näkemys täydentää määritelmää: tekstilaji on konventionaalista diskursiivista toimintaa, jossa yksilöt tunnistavat toistensa kommunikatiiviset tarkoitukset, mutta myös rajoitukset, jotka liittyvät tarkoituksen toteutumiseen, viestien tulkitsemiseen ja kielenkäytön ehtoihin (Bhatia 2004, 87).

Bhatia $(2004,88)$ on todennut, että markkinointihenkisyys on ottanut jalansijaa monissa ammatillisissa tekstilajeissa, myös tilinpäätöstiedotteissa (myös Henry 2008; Pander Maat 2007). Tiukasti normitetuissa teksteissä on usein nähtävissä, Bhatian käsittein, tiettyjen toisten tekstilajien piirteiden omaksumista (appropriation). Varsinainen genrejen sekoittuminen ymmärretään niin, että teksti saattaa sisältää erilaisia, jopa ristiriitaisia elementtejä (Solin 2006, 87; Fairclough 2003). Se on tuttua esimerkiksi vuosikertomuksissa, erityisesti tiedottavan ja myyvän aineksen sekoittumisena (Bhatia 2004, 89-90). Bhatia on tutkimuksessaan (2010) korostanut myös ammatillisten kulttuurien merkitystä tekstilajin merkityspotentiaalille ja analysoinut eri ammattikäytäntöjen kohtaamista teksteissä. Hän näkee ammatillisten käytänteiden ja kulttuurien liittyvän diskursiivisiin käytänteisiin, kun taas vuorovaikutuksessa teksti on kiinteässä suhteessa kontekstiinsa (emt., 33-34).

Tässä artikkelissa analysoin tuloksenhallinnan keinoja ja sen pohjalta teen päätelmiä siitä, missä on genren joustovara ja ovatko objektiiviseksi mielletyn tekstilajin, tilinpäätöstiedotteen, tunnistettavuus ja sitä kautta uskottavuus sijoittajaviestinnässä uhattuina. Käytännöllisenä kontribuutiona on keskustelun avaaminen siitä, miten tilinpäätöstiedotteita kirjoitetaan pörssiyhtiöiden arjessa. Metodinen kontribuutio liittyy yritysviestinnän tutkimuksen avartamiseen funktionaalisen tekstilajin tutkimuksen suuntaan. Yritysviestinnän näen strategisena viestintänä: yhteisöviestintä on 
johtamisen käytäntö, ja tutkimuksessa kohteena on se, miten organisaatiot esittelevät ja mainostavat itseään sekä miten ne ovat vuorovaikutuksessa yleisöjensä kanssa (Hallaghan ym. 2007, 16).

\section{Tilinpäätöstiedotteen konteksti}

Tekstin konteksti nousee tutkimuskohteeksi erityisesti diskurssintutkimuksessa, jossa pelkän tekstin sijaan tarkastellaan laajemmin kielenkäyttöä (Pietikäinen \& Mäntynen 2009, 24, 29). Keskiössä on sen pohtiminen, mikä kaikki tekee tekstin mahdolliseksi: miksi yhteiskunnassa samassa tilanteessa olevat yhteisöt, tässä pörssiyhtiöt, kirjoittavat juuri tilinpäätöstiedotteita ja suhteellisen samanlaisia tekstejä? Tilinpäätöstiedotteen kontekstissa merkityksellistä on se, että se on säännöllisen tiedonantovelvollisuuden täyttämistä, ei vapaaehtoista viestintää. Se välitetään samanaikaisesti kaikille intressiryhmille pörssin ja uutistoimistojen kautta. Se on talousviestintää, mutta myös yhtiön profiloimiseen tähtäävää sijoittajasuhteiden hoitamista (esim. Ikäheimo \& Mouritsen 2007). Tilinpäätöstiedote kiinnostaa institutionaalista sijoittajaa, meklaria, analyytikkoa, mediaa ja yksityissijoittajaa, mutta myös yhtiön omaa henkilöstöä. Lisäksi suuri yleisö on välillisenä kohderyhmänä, jolle media välittää tietoa yhtiön vuoden tuloksesta ja samalla tilinpäätöstiedotteesta tekemänsä tulkinnat.

Tilinpäätöstiedotteesta on tietotekniikan kehittymisen myötä tullut teksti, jonka suhteen aika on rahaa: ensimmäiset kaupat osakkeella tehdään vain muutamien sekuntien kuluttua siitä, kun pörssitiedotteen ensimmäiset rivit ovat ilmestyneet tietokoneen näytölle. Kaukana ei kuitenkaan ole aika, jolloin pörssitiedotteita toimitettiin pörssiin taksilla, myöhemmin faksilla (Kariola ym. 2004). Tiedonvälitys on nopeutunut merkittävästi viime vuosikymmeninä, ja sillä on oletukseni mukaan ollut vaikutusta siihen, millaiseksi tilinpäätöstiedote ja erityisesti sen alkuosa on muotoutunut.

Tekstin kirjoittaja tekee aina valintoja, jotka liittyvät asiasisältöön, informaation järjestymiseen, kielelliseen esitystapaan ja tekstin ulkoasuun (Halliday 1994). Hänen valintojaan ohjataan diskurssiyhteisössä, tekstin käyttöyhteisössä. Pörssitiedotteiden laatijoita on tavattu ohjeistaa laatimaan tiedote niin, että tiedotteen ensimmäisiltä riveiltä löytyvät yhteenvedonomaisesti esitettyinä keskeiset tiedot asiasisällöstä (Internet-pörssitiedoteohje 1999). Pörssitiedottamista ohjaavat monet lait, asetukset ja säännöt. Nykyisin (vuonna 2012) varsinaista tilinpäätöksen tekoa ohjaillaan kansallisesti ja Euroopan tasolla IASB:n ohjein (International Acconting Standards Board), ja Euroopan unionin avoimuusdirektiivin (MiFiD) velvoitteet sisältyvät arvopaperimarkkinalakiin. Tilinpäätöksen laadinnan ohjeistuksessa ajetaan laajaa harmonisoimista tietojen vertailukelpoisuuden vuoksi.

Mahdollisen tuloksenhallinnan ja manipuloinnin näkökulmasta tilinpäätöstiedotteen määritelmät ja laadintaohjeet ovat kiinnostavia. Tilinpäätöstiedote tuotetaan sähköistä välitystä ajatellen: teksti on kirjoitettava niin, että kirjasimena on Courier, lihavointeja tai muita korostuskeinoja ei saa käyttää (Internet-pörssitiedote 1999). Pelkistämisellä pyrittäneen siihen, että lukijan huomio ei kiinnity mihinkään muuhun 
kuin objektiiviseksi tarkoitettuun asiasisältöön. Tilinpäätöstiedote on siis visuaalisesti neutraali (Martin \& Rose 2003, 175; Heikkinen 2004). Säännöissä tilinpäätöstiedote määrittyy lehdistötiedotteen sukulaisgenreksi: se informoi neutraalisti eikä pyri ensisijaisesti myymään eikä suostuttelemaan vaan kertomaan asian mahdollisimman selkeästi ja ymmärrettävästi (tiedotteen tehtävästä Juholin 2009, 179). Elisa Juholinin yhteisöviestinnän määrittelyissä tilinpäätöstiedottaminen on yrityksen mediaviestinnässä rutiiniviestintää ja informointia (Juholin 2009, 239). Yleisesti tiedotteen tärkeitä ominaisuuksia ovat sisältö ja uutisarvo, rakenne ja ymmärrettävä kieli (emt.). Tiedotteista erityisesti lehdistötiedote usein esimuotoilee median laatiman uutisen (Sleurs ym. 2003; Lassen 2006, 508). Se on siis joko suoraan tai muokattuna uutisen raakaainetta, millä on vaikutusta tiedotteen, myös tilinpäätöstiedotteen, laadintaan.

Lehdistötiedote sisältää usein sitaatin, joka laajentaa tietoa (Lassen 2006, 508, 523) mutta jota Sleurs ja kumppanit (2003) pitävät näennäisenä vuorovaikutuksen rakentamisena. Inger Lassen pitää lehdistötiedotetta välityskanavana pikemminkin kuin tekstilajina: sen päätehtävä on tulla uudelleen muotoilluksi toisessa tekstissä, yleensä uutisessa (emt. 503-504). Lisäksi tiedote on uutisen objektiivinen tekstimuotovariantti, mikä velvoittaa kirjoittajaa faktapohjaisuuteen (tekstityypeistä ja -muodoista ks. Werlich 1976). Tilinpäätöstiedottamisessa keskeistä on siis kertoa vähintään ne tiedot, jotka yhtiön edellytetään kertovan. Valinnalle sen sijaan jää tilaa siinä, miten asiat esitetään ja missä järjestyksessä.

Pörssiyhtiö kilpailee jatkuvasti muiden sijoitusvaihtoehtojen kanssa sijoittajien ja median huomiosta, ja tilinpäätöstiedote on yhtiölle yksi sijoittajaviestinnän väline. Pörssitiedotteella on ammattilaisten yhteisössä oma yksilöllinen identiteettinsä (Bhatia 2004, 87). Genreillä pidetään yllä ammatillista solidaarisuutta, ja siitä syystä Bhatian mukaan diskurssiyhteisössä olisi suositeltavaa viestiä samassa tilanteessa yhtäläisesti (emt., 21), kulttuuristen odotusten mukaisesti (Ventola 2006, 104). Genret siis elävät sosiokulttuurisessa kontekstissaan, ne on luotu kunkin ajan ja sosiaalisen yhteisön kontekstiin ja tarpeisiin.

\section{Tilinpäätöstiedote pörssiyhtiön ulkoisessa viestinnässä}

Tilinpäätöstiedotteet ovat siis osa pörssiyhtiön säännöllistä tiedonantoa, sijoittajasuhteiden hoitoa. Benjamin Cole $(2004,28)$ näkee sijoittajasuhteiden hoitamisen monien ammattilaisten toimintakenttänä (myös Ikäheimo \& Mouritsen 2007, 65 ja Bhatia 2010). Sekä talousanalyysi- että markkinointitaitoja tarvitaan, mikä näkyy Colen mukaan sijoittajaviestinnän määritelmästä (NIRIn' mukaan):

Sijoittajasuhteiden hoitaminen (Investor Relations, IR) on strategisen johtamisen vastuualueella. Se on neljän funktion rajapinnassa: rahoituksen, viestinnän ja markkinoinnin sekä arvopaperimarkkinoiden lainsäädännön. Neljä funktiota integroimalla sijoittajasuhteiden hoitajat tuottavat kahdensuuntaista viestintää yhtiön, rahoitusmarkkinoiden ja muiden tahojen välille. Tämä viestintä auttaa siinä, että osake on oikein arvostettu. ${ }^{2}$ 
Laskentatoimen tutkijat Seppo Ikäheimo ja Jan Mouritsen $(2007,66)$ täydentävät määritelmää: sijoittajasuhteiden hoitaminen on viestinnällisiä toimenpiteitä, joilla neuvotellaan umpeen epävarmuuskuilua sijoittajien ja yhtiön välillä. Oletuksena on, että molemmat tahot ovat epävarmoja toistensa toimista. Viestintä vähentää epävarmuutta ja vaikuttaa suhteeseen, joka vallitsee ulkoisen markkina-arvostuksen ja yhtiön oman näkemyksen välillä siitä, mikä on yhtiön oikea arvo. Tutkijat korostavat kolmen eri tietolähteen merkitystä yhtiön arvioimisessa: taloudellinen suoriutuminen (lähinnä historiallinen numerotieto), strategia (kontekstualisoitu käsitys yrityksen tulevaisuudesta) sekä kompetenssi (yrityksen mahdollisuudet toteuttaa strategiaansa ja päästä entistä parempiin tuloksiin). (Emt., 70-72.)

Yhdysvalloissa pörssiyritysten tilinpäätöstiedotteiden informaation välittymistä ovat tutkineet muiden muassa taloustieteilijät John R. Graham, Campbell R. Harvey ja Shiva Rajgopal (2005). Haastattelututkimuksessa todetaan, että Yhdysvalloissa noteerattujen yhtiöiden tilinpäätöstiedotteiden informaation järjestys erityisesti tiedotteen alun tiivistelmässä on tarkoin harkittu. Erityisesti osakekohtainen tulos (earnings per share, EPS) on noussut keskeiseksi sisällöksi. Osakekohtaisen tuloksen nosto tekstin kärkeen on yleistynyt 1980-luvulla ja korostunut Internetin nousun myötä. Talousjohtajien mukaan sijoittajat tarvitsevat yhden selvän ja ymmärrettävissä olevan vertailtavan luvun, kun taloudesta raportoitavia lukuja on paljon.

Lisäksi osakekohtainen tulos on se asiasisältö, jonka media nostaa herkimmin otsikoihin (Graham ym. 2005; Kuningas 2004). Solja Kuningas totesi tutkimuksessaan, että Suomessa eri mediat suosivat erilaisia juttutyyppejä: esimerkiksi Taloussanomat. fi suosi 2000-luvun alussa uutisten kärkenä yhtiön tulosta analyytikoiden odotuksiin nähden. Myös Grahamin ja kumppaneiden (2005) mukaan tärkeänä pidetään tulokseen liittyvien odotusten täyttämistä, sekä omien ennustusten toteutumista että analyytikoiden konsensusennusteiden täyttymistä.

Tuloksenhallinnan motiiviksi on todettu uskottavuuden ja maineen rakentaminen eri sidosryhmien keskuuudessa (Graham ym. 2005). Toisin kuin aiemmissa tutkimuksissa Graham ja kollegat havaitsivat, että talousjohtajien omat välittömät bonuspalkkiotoiveet eivät ohjaakaan tiedottamista niin vahvasti kuin on oletettu. Sen sijaan omat uranäkymät ja maine työmarkkinoilla ovat tärkeitä vaikuttimia ennustetun tuloksen saavuttamisessa. (Emt., 67.)

Taloustiedottamisen moniin sidosryhmiin kiinnittävät huomiota tutkimuksessaan Elaine Henry (2008) sekä Kari Koljonen ja Heikki Heikkilä (2002). Henryn mukaan taloustiedotteen kirjoittajat kohdistavat tekstin sijoittajille, analyytikoille ja toimittajille (Henry 2008, 368). Henryn tutkimus osoittaa myös, että osavuosikatsaukset ${ }^{4}$ voi- $^{2}$ daan kirjoittaa niin, että kirjoitustavalla vaikutetaan viestin positiiviseen tulkintaan. Viestin sävy vaikuttaa sijoituspäätökseen: numerotiedon kehystäminen tekstissä positiivisesti saa sijoittajat tulkitsemaan yhtiön tuloksen kasvavaksi. Positiivista kehystämistä on muun muassa taulukoiden erien valikointi. Jos esimerkiksi liikevaihto pieneni mutta nettotulos parani, puhuttiin tekstissä jälkimmäisestä. Yhtenä tekniikkana on myös positiivisen tiedon painotus niin, että se sijoitetaan tekstiin korosteisesti tai sitä toistetaan taikka molempia. Myös vertailuperiodin valinta voi toimia retorisena 
tekniikkana. Henry tulkitsee, että tällaisessa raportoinnissa kirjoittajan tarkoituksena on paitsi informoiminen myös osakkeen myyminen. (Emt., 363-373.) IImeisinä lukijan tulkintoja ohjailevina keinoina Henry pitää myös positiivisesti arvioivia sanoja ja kommentteja, kuten olemme erittäin tyytyväisiä kolmannen neljänneksen tulokseen tai vahva tulos. Henry korostaa, että kyseiset kirjoittajien myyntihenkiset valinnat ja tekniikat kuitenkin samalla informoivat sijoittajaa: yhtiö kertoo toimintansa kannalta tärkeänä pitämiään asioita. (Emt., 374.)

Tilinpäätöstiedotteiden tuottamisen prosessia on analysoitu suomalaisella, yhden yritystapauksen aineistolla (Koljonen \& Heikkilä 2002). Elcoteqiä käsitelleen tutkimuksen tulokset ovat monilta osin linjassa Grahamin ja kumppaneiden (2005) tutkimuksen tulosten kanssa. Elcoteqin hallitus muokkasi tilinpäätöstiedoteluonnosta muun muassa karsimalla sisältöä niin, että positiiviset asiat korostuivat. Muokkaus oli tulkittavissa niin, että yhtiö pyrki ohjaamaan lukijan tulkintoja yhtiölle myönteiseen suuntaan. Tiedoteluonnosta muokattaessa "mahdottomaksi" luonnehdittu tulevaisuuden ennustaminen vaihtui yhtiön aktiivisuutta korostavaan muotoon: "keskeinen tavoite on myynnin lisääminen ja kannattavuuden merkittävä parantaminen loppuvuonna 2002". (Koljonen \& Heikkilä 2002, 10-11.) Markkinointihenkisyyttä tarkasteltiin Elcoteqissa kuitenkin myös kriittisesti pelkona se, että yhtiön uskottavuus voisi kärsiä (emt.). Hienovaraisina muokkausstrategioina olivat muun muassa abstraktiotason nosto, kielteisyyttä korostavien tehostesanojen poisto ja kielteisen asian esittäminen myönteisessä kontekstissa. Tiedotteiden kirjoittajat luottivat neutraaleihin ja niukkoihin ilmauksiin. (Emt., 13.)

Tutkimuksissa havaitut kielelliset ja retoriset valinnat voidaan tulkita yhtiön profiloimiseksi (Ikävalko 1996; Henry 2008). Yrityksen profiloiminen kielellisesti on tullut erityisesti 2000-luvun alussa entistä verhotummaksi, jopa siinä määrin, että virhetulkinnat ovat mahdollisia (Henry 2008, 212). Vaikka ekspertin on helppo seuloa informaatiota tarkoituksiltaan monipuolisesta tekstistä, ei se Bhatian mukaan merkitse sitä, että tiedottavan viestin mukauttaminen profilointi- ja myyntimielessä olisi soveliasta tekstissä kuin tekstissä $(2004,95)$. Viestintää häiritsevät genrekonfliktit ovat mahdollisia. Tutkimuksissa tulee esiin muun muassa toivomus siitä, että erityisesti Internetin muuttamassa viestinnän kentässä taloudellista ja ei-taloudellista tietoa välitettäisiin niin, että tieto olisi nopeasti luettavissa ja omaksuttavissa sekä vertailukelpoista niin yhtiön omaan historiatietoon kuin muidenkin yhtiöiden tietoihin (Seetharaman \& Subramanian 2005).

\section{Tutkimuskohde, aineisto ja menetelmät}

Tutkimuskohteenani ovat tilinpäätöstiedotteet tekstilajina sijoittajaviestinnässä. Teoreettisemmin kohteena on tekstiin tulkittavissa olevien sosiaalisten ja diskursiivisten käytäntöjen vuorovaikutussuhde niin, että kontekstin käsitettä käytetään selittämään kielellisiä käytäntöjä (esim. Bhatia 2010). Tällainen määritys tarkoittaa sitä, että esimerkiksi yrityksiä ei tarkastella pelkästään diskursiivisina objekteina, vaan keskiössä 
pidetään diskursiivisten ja muiden sosiaalisten elementtien suhteita. (Chouliaraki \& Fairclough 2010, 1214-1215.) Tilinpäätöstiedotteista analysoitavana ovat aloitusjaksot, otsikot ja tiivistelmät, sekä tekstikokonaisuuden rakentuminen. Analyysilla saadaan tietoa tuloksenhallinnan kielellisistä ja diskursiivisista keinoista sekä ammatteihin liittyvien käytäntöjen kohtaamisesta teksteissä.

Tämän artikkelin aineisto käsittää Helsingin pörssin New Market -listan (NM) ${ }^{5}$ yhtiöiden tilinpäätöstiedotteet keväältä 2006 (kaikki 10 tiedotetta) sekä päälistan yhtiöistä (yhteensä 106 vuonna 2006) 17 yhtiön tiedotteet. Otoksessa ovat edustettuina kaikki toimialat ${ }^{6}$. Yhtiöt ovat erikokoisia sekä tuote- ja palvelukonseptiltaan erilaisia, jotta vältettäisiin mahdollinen toimialakulttuurin tuloksia vääristävä vaikutus. Aineisto on vuodelta 2006 siksi, että näin voidaan tarkastella New Market -listalla olleiden lyhyen pörssi-iän (6-7 vuotta vuonna 2006) yritysten sijoittajaviestintää suhteessa kokeneiden viestintään (pörssi-iän vaikutuksista Kariola ym. 2004, 102). Toimialakohtaista vertailua ei tässä tutkimuksessa tehdä. ${ }^{7}$

Tällä suomalaisella aineistolla vertaan omia tuloksiani niihin, joita on saatu ulkomaisissa tutkimuksissa tuloksenhallinnasta (Graham ym. 2005; Pander Maat 2007). Haluan myös laventaa ulkoisen yhteisöviestinnän tutkimusta tekstien analyysiin. Esimerkiksi Risto Kunelius on korostanut journalismin tutkimuksessa tekstien tutkimista eri näkökulmista niin, että eri tutkijoilla on sama kohde, josta ei koskaan voida kuitenkaan lausua mitään absoluuttista totuutta. Kuneliuksen tapaan haluan korostaa myös sitä, että tärkeää on tehdä näkyväksi keskustelua siitä, mitä kohde (Kuneliuksella journalismi) merkitsee tai voi merkitä tuottajille, lukijoille ja tutkijoille. (Kunelius 1996, 377.) Lisäksi tämä artikkeli jatkaa keskustelua sijoittajaviestinnän suunnittelusta yhtiön profiloimisen mielessä (Koljonen \& Heikkilä 2002). Esimerkiksi Ikävalko (1996) on määritellyt profilin organisaation tavoitekuvaksi, jonka se on itselleen asettanut oman identiteettinsä pohjalta, ja organisaation kehittäminen eli profilointi pitkäjänteisesti on keskeinen viestintätehtävä.

Tilinpäätöstiedottamisen yleisöksi oletan muutkin tahot kuin toimittajat, jotka välittävät tietoa eri yleisöille (ks. Koljonen \& Heikkilä 2002). Tärkeitä tiedotteiden lukijoita tässä mielessä ovat analyytikot ja pörssimeklarit. Tilinpäätöstiedotteiden tavanomaiset lukijat seuraavat osavuosikatsauksia ja pörssitiedotteita pitkin vuotta. He siis lukevat tilinpäätöstiedotteita jatkokertomuksen osina ja suhteuttavat niitä aiempaan tietämykseensä yrityksistä.

Tekstien sävyä ja tyyliä ei voi saada selville kvantitatiivisesti tutkien, hienovaraiset ja monipuoliset tulkinnat voi saada esiin vain yksittäisten yhtiöiden tekstejä analysoiden (Henryn 2008, 396). Kielenkäytön ja sosiaalisen toiminnan välinen yhteys (Pietikäinen \& Mäntynen 2009, 165) tulee esiin analysoitaessa eri ammattien edustajien kohtaamista tekstissä (Bhatia 2010). Hyödynnän Bhatian kehittämää genreanalyysin mallia (2004), jota hän on myöhemmin (2010) täydentänyt korostaen aiempaa enemmän ammatillisen kontekstin merkitystä tekstilajitoteutukselle sekä diskurssienvälisyyttä. 


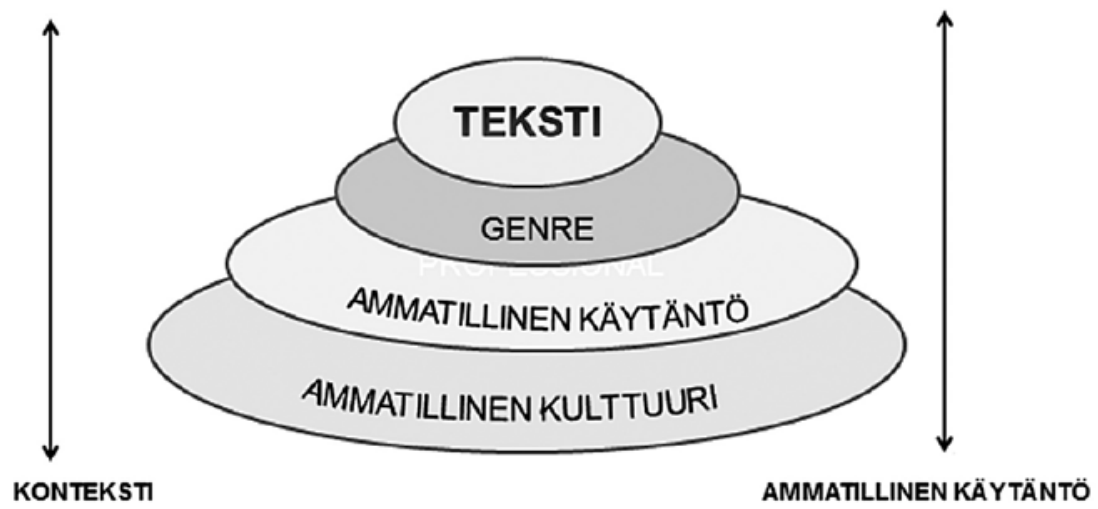

Kuva 1. Diskurssin edustukset ammatillisessa kontekstissa (Bhatia 2010, 34)

Genreanalyysissa keskiössä on tekstin rakenne. Tekstilajille tyypillisellä rakenteella on merkitystä informaatiovirralle (information flow). Michael Halliday (1994) samoin kuin Jim Martin ja David Rose (2003, 175-177) kuvaavat tekstin jaksottumista käsitteellä informaatioaalto (information wave). Aaltojen määrää sekä pienten ja suurten aaltojen sijoittelua säätelemällä kirjoittaja pystyy ilmaisemaan jonkin asian tärkeyttä. Tärkeyden huippu lauseen alussa on yleensä teema, puheenaihe (emt., 177). Aaltoja tekstiin rakentamalla lukijan odotukset saadaan heräämään tai ne estetään. Tekstilajeittain voidaan tarkastella esimerkiksi sitä, onko niiden informaatiovirrassa vakiintunutta jaksoittaisuutta. (Emt.)

Rakenteen ja informaatiojärjestyksen analyysissa keskityn tilinpäätöstiedotteiden aloitusjaksoihin suhteuttaen niitä kokonaisen tekstin rakenteeseen. Koko tekstin aloittavan ensimmäisen virkkeen on todettu olevan tärkein uutisen osa (Luoma-aho ym. 2011, 52). Tekstistä voidaan erottaa tekstilajin toiminnan kannalta välttämättömät osat ja valinnaiset osat (Hasan 1989; Swales 1990; Bhatia 1993) tai tyypilliset osat (Bex 1996) - pörssin ohjeiden mukaan otsikko ja tiivistelmä ovat tilinpäätöstiedotteen välttämättömiä osia. Rakenteen analyysi antaa tietoa siitä, etenevätkö tilinpäätöstiedotteet odotusten, ja jos etenevät, kenen odotusten mukaisesti. Osa kulttuurisista odotuksista on julkilausuttuja (kuten arvopaperipörssin säännöt, arvopaperimarkkinalaki), osa on tekstin käytön motivoimaa: kirjoittaja tietää, että lukija käyttää tietoa sijoituspäätöksentekoon, mutta myös sijoituskohteen valintaan tai lehtiuutisen tekoon. Kulttuuri ei kuitenkaan ilmene sana- tai lausetasolla vaan kokonaisen tekstin tasolla: millaisia lauseita ja missä järjestyksessä, millaisia tekstijaksoja? Mitä sanotaan tyypillisesti ensin, mitä sitten? Ohjataanko lukijaa metatekstin ${ }^{8}$ avulla? Autetaanko häntä ymmärtämään tekstiä? (Bhatia 2004; Pietikäinen \& Mäntynen 2009; Mauranen 1993.)

Kielellisten ja kieliopillisten resurssien analyysissa analysoitavina ovat tekstin nimeäminen ja erilaiset kielelliset piirteet (genren analysoimisesta esim. Mäntynen \& Shore 2006, 284-297). Analyysi on yhteisöllistä, eli tekstin aito tuottamis- ja käyttöyhteisö 
otetaan huomioon (tekstin puitteet ja konteksti sekä ammatilliset käytänteet; Bhatia 2010), koska tekstin tuottamisen ja käyttämisen kontekstit vaikuttavat ratkaisevasti tekstilajiin (Heikkinen 2004; Mäntynen \& Shore 2006, 284; Bhatia 2004).

Rakenteen tulkinnassa aktivoituu samalla ideologisia ja kommunikatiivisia merkityksiä, jotka ovat tekstin diskursseja (Fairclough 2003). Peter Verdonkin ja Bhatian tapaan tulkitsen myös diskursseja, koska analysoitavana ei ole pelkästään kielellisiä piirteitä vaan myös ei-kielellisiä aspekteja, kuten tekstinulkoinen viestintäkonteksti ja ammatilliset käytänteet, joihin diskurssi sijoittuu (Verdonk 2002, 2; Bhatia 2010). Tekstejä tutkivaa kiinnostaakin yleisesti kaksi ilmiötä: muutos suhteessa pysyvyyteen sekä sosiaalinen todellisuus, jonka tekstit itselleen rakentavat. Diskurssintutkijan tapaan myös genretutkija on kiinnostunut paitsi merkitysten kielellistymisestä myös siitä, miten sosiaalinen toiminta organisoi merkityksen rakentumista ja päinvastoin (Ridell 2006; Pietikäinen \& Mäntynen 2009, 166).

Tarkastelen tilinpäätöstiedotteita myös retoristen tarkoitusperien näkökulmasta (Lassen 2006, 526; Fairclough 2003, 68; Perelman \& Olbrecht-Tyteca 1971). Genre on Bhatian mukaan retorinen strategia, jonka avulla tieto järjestetään yhteisön tavoitteiden saavuttamiseksi (Bhatia 2004, 179). Retorisessa tarkastelussa kyseessä on ensinnäkin viestinnän sosiaalinen näkökulma: puhujan, yleisön ja tilanteen suhteet (retorisen analyysin tasoista ks. Kakkuri-Knuuttila 1998, 240). Toiseksi analysoidaan kieltä eli retoristen keinojen käyttöä tekstikokonaisuudessa. Kieli tarjoaa monenlaisia valinnan mahdollisuuksia. Erilaiset määreet, kieliopilliset kategoriat, nimeäminen, ajatusten erilaiset ilmaisutavat ja niiden väliset sidokset mahdollistavat esityksen hierarkkisen jäsentämisen, esimerkiksi yhden asian korostamisen toisen kustannuksella (Perelman 1996, 54-55). Kirjoittaja voi valinnoillaan vakuuttaa kuulijan tai suostutella häntä. Vakuuttamiseen pyrkivässä viestinnässä asiat esitetään faktuaalisesti kuvauksena, raporttina: miten asiat todella ovat (Jokinen 1999, 129; Kakkuri-Knuuttila 1998, 237). Suostuttelevaksi taas voidaan katsoa tyyli, joka tavoittelee yleisön älyllistä tai emotionaalista hyväksyntää (Perelman 1996, 181) ja joka voi esimerkiksi sisältää virheargumentteja tai epäreilua argumentointia (Kakkuri-Knuuttila 1998, 237).

Kiinnitän analyysissa huomiota retoristen tavoitteiden ja diskurssien sekoittumiseen sekä niiden myötä tekstilajien sekoittumiseen (genre mixing, Bhatia 2004) tai joustamiseen (genre bending, emt.; Ridell 2006; Pietikäinen \& Mäntynen 2009). Eija Ventola on kuitenkin huomauttanut, että abstraktio tekstilaji ei sellaisenaan sekoitu toiseen vaan tilanteista tekstilajia rakentavat erilaiset resurssit (Ventola 2006, 93; Fairclough 2003, 68). Analyysini tulokset määrittävät samalla tekstilajin manipuloimisen rajoja rahoitusmarkkinoiden kontekstissa (Bhatia 2004, 78; Ikäheimo ja Mouritsen 2007; Ridell 2006) sekä ammatillisten kulttuurien kohtaamista teksteissä (Bhatia 2010).

Tekstiaineistoja käyttävälle laadulliselle tutkimukselle tyypillisesti en pyri ensisijaisesti tulosten yleistettävyyteen vaan ns. siirrettävyyteen (transferrability, KakkuriKnuuttila \& Heinlahti 2006, 175-176): tutkimus ei pyri esittämään yleisiä säännönmukaisuuksia vaan paljon yksityiskohtia, joita on analysoitu yleisempien käsitteiden avulla ja joiden merkitystä lukija voi arvioida muissa tapauksissa. 


\section{Tuloksenhallintaa rakenteen suunnittelulla}

Ensimmäinen tutkimuskysymykseni liittyy siihen, miten tuloksenhallintaa toteutetaan suomalaisissa tilinpäätöstiedotteissa. Tutkimukseni osoittaa, että yksi keino hallita tulosta on valita tekstin aloitusjakson asiasisällöt ja muotoilla koko tekstin rakenne omia tarkoitusperiä tukevasti. Tiedotteen laadintaohjeen käsite yhteenveto on tulkittu monella tavalla, samoin se, mitä ovat keskeiset tiedot. Yhteistä linjaa tiedotukselle ei näytä olevan (myös Finanssivalvonta 2010 talousraporteista).

Arvopaperipörssi ei anna erikseen ohjeita informaation esittämisjärjestyksestä (ei myöskään Fiva, ks. Finanssivalvonta 2009a; 2009b). Ohjeiden puute näkyy aineistossa. Tilinpäätöstiedotteen määritelmässä lukijan odotushorisontiksi määrittyy uusi tieto yhtiöstä: teksti nimetään tiedotteeksi, ja sen tehtävänä on raportoida yhtiön tuloksesta ja toiminnasta kuluneen vuoden ajalta. Asiasisältöjen jaksotuksella kirjoittaja siis viestii paitsi omaa käsitystään uudesta asiasta ja lukijan odotuksista myös muita taustaoletuksiaan ja retorisia tavoitteitaan (Fairclough 1992; Eggins \& Martin 1997).

Helsingin pörssin päälistan yhtiöiden ja NM-listan yhtiöiden pörssitiedotteissa on nähtävissä pääpiirteissään jaksotuksia, jotka ilmentävät kolmenlaista tekstin kokonaisrakennetta ja sitä, että tilinpäätöstiedote on hybriditeksti, tekstilajeja yhdistävä, ei vain lajipiirteitä sekoittava (Solin 2006, 90). Tekstilajin hybridiluonteesta on osoituksena muun muassa toimitusjohtajan kommentti sitaattina Neste Oilin ensimmäisen toimintavuoden tiedotteessa (ks. Liite 1; sitaateista Lassen 2006; Sleurs ym. 2003). Se ilmentää yleisesti pörssitiedotteen genren mukautumisesta lehdistötiedottamiseen. Jaottelin analyysissa tiedotteet kolmeen rakennetyyppiin, jotka on kuvattu taulukossa 1.

\begin{tabular}{|l|c|c|}
\hline & Päälistan yhtiöt (17) & NM-listan yhtiöt (10) \\
\hline $\begin{array}{l}1 \text { Hallituksen toimintakertomus upotettuna } \\
\text { tilinpäätöstiedotteeseen }\end{array}$ & 3 & 1 \\
\hline $\begin{array}{l}2 \text { Hallituksen toimintakertomus } \\
\text { tilinpäätöstiedote }\end{array}$ & 10 & 8 \\
\hline $\begin{array}{l}3 \text { Kahden tekstin rakenne: } \\
\text { lehdistötiedote + tilinpäätöstiedote }\end{array}$ & 4 & 1 \\
\hline
\end{tabular}

Taulukko 1. Tilinpäätöstiedotteiden rakenneratkaisut vuonna 2006 (27 yhtiötä)

Tiedotetyypissä 1 hallituksen toimintakertomus on erillisenä jaksona pörssitiedotteen otsikon ja (useimmiten) luetelmamuotoisen tiivistelmän jälkeen; väliotsikkona voi olla myös tilinpäätöstiedote tai konsernikatsaus. Tyypin 2 tilinpäätöstiedote on implisiittisesti toimintakertomus: tilinpäätöstiedote sisältää toimintakertomuksen tiedot, mutta toimintakertomus-väliotsikkoa ei käytetä. Tyypissä 3 on lehdistötiedotetta jäljittelevä tiedote alussa, ja sitä seuraa toimintakertomukseksi nimetty tekstijakso (ks. Liite 1). Lehdistötiedotteelle tyypillisesti (esim. Lassen 2006) tällainen tilinpäätöstiedote sisältää toimitusjohtajan sitaatin, eli johdon tulkinnan vuodesta, sekä yhteystiedot. 
Rahoitustarkastuksen (nykyisen Finanssivalvonnan) suosituksia ja arvopaperipörssin ohjeita näytetään noudatettavan tilinpäätöstiedotteissa pääosin. Vähiten ohjeistettu asia on informaatiojärjestys, mikä näkyy tekstin rakenteesta: se vaihtelee lehdistötiedottamisen luonteisesta ohjeita tarkasti noudattavaan tiedottamiseen. Valinnan mahdollisuuksista huolimatta tilinpäätöstiedote ei kuitenkaan etene sattumanvaraisesti. Tekstilajin tunnistettavuuden turvaavat lopulta tiedotteen alun tunnistejaksojen otsikoiden yhtenäisyys, erityisesti päälistan yhtiöiden kohdalla, ja toisaalta asiasisällön yhtenäisyys.

\section{Tuloksen hallintaa tyylivalinnoilla}

Tarkastelen tuloksenhallinnan keinoja ja ammattikäytäntöjen kohtaamista tilinpäätöstiedotteessa analysoimalla tiedottelen kielen piirteitä ja diskursiivisia käytäntöjä, jotka vaikuttavat tyyliin. Keskityn erityisesti niiden aloitusjaksoihin eli otsikoihin ja tiivistelmiin.

Tilinpäätöstiedotteet toimivat pörssiyhtiöiden ja niiden rahoittajien maailmassa. Otsikoiden merkitysten tulkinnassa aktivoituvatkin globaalin markkinatalouden ja rahoitusmarkkinoiden diskurssit. Lisäksi tulkittavissa on taloudellisen tehokkuuden diskurssi, jota rakennetaan tuloksellisuuden mittaamisen varassa (tulos, kasvu, kannattavuus). Kolmanneksi diskurssiksi tulkitsen kehitysdiskurssin, joka ilmenee dynaamisista verbeistä, joiden merkitykseen sisältyy vertailu (nousta, parantua, tehostaa; kehitysdiskurssista myös Henry 2008, 400). Huomattavaa on, että otsikoissa dynaamiset verbit vievät tässä kontekstissa kehitystä aina parempaan suuntaan. Tässä maailmassa ei ole mahdollista jäädä paikalleen. Kehitysdiskurssi ilmentää tulevaisuudenuskoa. Diskurssit ovat pörssimaailmaan luonnollistuneita.

Journalismin ja yhteisöviestinnän kirjallisuuden mukaan otsikko on keskeinen elementti tekstissä, erityisesti tiedotteessa, uutisessa tai lehtijutussa (esimerkiksi Juholin 2009; Manning 2001; Majapuro 2006). Mediassa otsikko myy uutisen, joka kilpailee lukijan huomiosta toisten uutisten kanssa. Tilinpäätöstiedotteiden otsikoista osa on tyyliltään myyviä tai positiivista arviointia ilmaisevia (liiketoimintasegmentit paransivat tulostaan). Toisaalta teksteissä huomioidaan laaja lukijakunta, varsinkin toimittajat ja yksityissijoittajat. Oletukseni on, että institutionaaliset sijoittajat ja analyytikot alan ammattilaisina suodattavat vaikuttavan kielenkäytön lomasta varsinaisen informaation (myös Pander Maat 2007). Tuloslukujen kommentointi otsikoissa ja niiden varariveillä on melko yleistä. Otsikoilla otetaan avoimesti kontakti lukijaan myyntipuheen tapaan, ja arviot osoittavat kirjoittajan suhtautumista asiaan (erinomainen; parantaa); kyseessä on lehdistötiedotetyylinen otsikko:

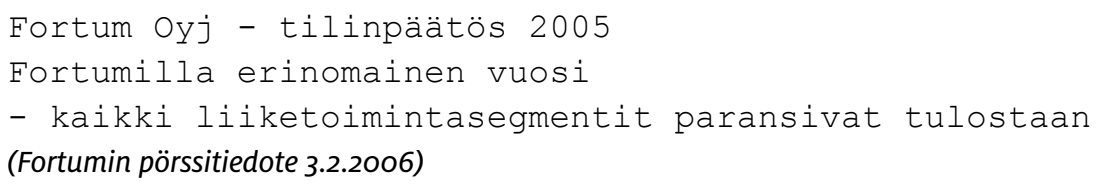


Positiivisuus tai myyvyys välittyy yleisesti adjektiiveista tai verbeistä (myös Beattie ym. 2008 ja Henry 2008): Eq-KONSERNIN VUOSI 2005: KANNATTAVUUS NOUSI HYVÄLLE TASOLLE. Myös määrän ilmaisun hieman voidaan nähdä ohjailevan lukijan tulkintoja:

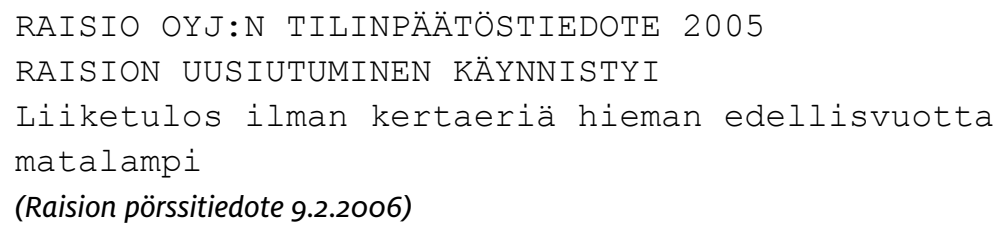

Hieman-sanalla pyrittäneen pehmentämään kielteistä asiaa, liiketuloksen laskua. Uusiutumisen käynnistymisen taustaoletuksena puolestaan on se, että uusiutumiselle on ollut aihetta eli heikko tulos ja että yhtiö on ymmärtänyt reagoida asiaan. Yksi tuloksenhallinnan kielellinen keino on otsikon pituus: lehdistötiedotetyylisissä tilinpäätöstiedotteissa tavallinen on jopa kolmen rivin mittainen otsikko (ks. Raision otsikot yllä), mikä mahdollistaa asiasisällön laajentamisen ja subjektiivisen arvioimisen. Neutraalisti ja objektiivisesti tuloksesta raportoivat otsikot puolestaan ovat lakonisia substantiivilausekkeita, tyyliin TECHNOPOLIS-KONSERNIN TILINPÄÄTÖS VUODELTA 2005. Tällainen otsikko ei sisällä yhtiön arviointeja vuodesta.

Positiivisuuden merkitys liittyy siis tuloksenhallintaan tilinpäätöstiedotteissa. Positiivisuus on joko sanan merkityksessä itsessään (uusiutuminen; kasvaa, nousta, tehostaa, parantua; hyvä, menestyksellinen) tai se sisältyy ilmauksiin, jotka liittyvät lukijan odotusten täyttymiseen: arvioiden mukainen; ilmaisulla raportoidaan yhtiön omien ennustusten toteutumisesta. Yhdysvaltalaiset talousjohtajat pitävät kaikkein tärkeimpänä sitä, että jo aloitusjaksossa vastataan sekä omiin että analyytikkojen konsensusennusteisiin, koska johdon pätevyyttä ja kyvykkyyttä saatetaan arvioida tämän kriteerin avulla (Graham ym. 2005, 27). Tiedot voivat myös enteillä hyvää tulevaisuutta yhtiölle. Petri Vehmanen $(2002,211)$ on todennut, että yhtiö lähettää tilinpäätösinformaatioon liittyen signaaleja tulevasta kehityksestä. Tällaisina signaaliarvoisina tietoina Vehmanen pitää esimerkiksi osingonjakotietoa ja vuositulosta.

Aineistossa (27 yhtiötä) oli vain kaksi tapausta, joissa oli negatiivinen ilmaus otsikossa: liiketulos hieman edellisvuotta matalampi ja kotimaan osalta jäätiin tavoitteesta. Edellinen on sanan merkityksen ja muodon sekä kontekstitiedon perusteella negatiivinen. Diskurssiyhteisön tiedon varassa tiedämme, että yhtiö ei tavoittele liiketulosta, joka olisi edellisvuotta matalampi. Tähän perustunee myös määritteen hieman käyttö, jolla pehmennetään negatiivista kehitystä. Jälkimmäisessä lausumassa puolestaan verbi (jäädä) osoittaa, että yhtiö ei ole onnistunut pääsemään tavoitteeseensa.

Otsikoista voidaan todeta tiivistäen, että lakisääteisten tietojen (tilinpäätös ja vuosiluku) lisäksi niihin saatetaan lisätä muita teemoja; noin puolet otoksen yhtiöistä toimi näin. Tilinpäätöstiedote muistuttaa tältä osin lehdistötiedotetta. Otsikointi on mielestäni osoitus siitä, että tiedotteen lukijaksi määrittyy sijoittajan ja analyytikon lisäksi toimittaja. Toimittaja saattaa poimia otsikon sellaisenaan oman uutisensa otsi- 
koksi (Juholin 2009, 234; Lassen 2006). Otsikointi on myös osoitus pörssitiedotteen genren piirteiden sekoittumisesta lehdistötiedotteen piirteisiin (Bhatia 2004). Samalla tekstissä kohtaavat taloushallinnon ja viestinnän ammattilaiset (Bhatia 2010).

Tuloksenhallinnan keinojen analyysissa tarkastelen otsikoiden lisäksi aloitusjakson tiivistelmiä. Ensimmäinen teema on yleensä liikevaihto, joka kasvoi, kohosi tai nousi; myös sijapääte voi välittää nousun merkityksen: tuotot 31,0 miljoonaan euroon. Dynaamisuutta ilmentävät valinnat liittyvät jatkuvuuden ja kehityksen diskurssiin. Graham ja kumppanit ovat todenneet tutkimuksessaan, että erityisesti verrattain nuoret yhtiöt sekä yhtiöt, jotka eivät harjoita tulosohjausta, fokusoivat tulosraportoinnin kassavirtaan tuottojen sijaan. Liikevaihdon korostamisen kautta tekstin lukijoiksi voi tulkita myös alihankkijoita, tavarantoimittajia ja asiakkaita, joille on tärkeää voida tehdä päätelmiä yhtiön toiminnan jatkuvuudesta. Viime kädessä kyseessä on yhtiön uskottavuus ja maine, jota halutaan vaalia. (Graham ym. 2005, 20, 27-28.)

Graham ja kumppanit (2005) havaitsivat, että tappiollinen yhtiö valitsee tiedotteen kärjeksi muita tietoja kuin tulostietoja, varsinkin itselleen edullisia asiasisältöjä yhtiön - ja myös talousjohdon - maineen säilyttämiseksi. Aineistoni yhtiöstä vain kaksi joutui julkistamaan tappiollisen liiketuloksen, yksi puolestaan huonon tuloskehityksen. Raisio kertoi monien muiden tapaan tiivistelmässä osakekohtaisen tuloksen, vaikka se oli negatiivinen, mutta se myös hyödynsi aloitusjaksoa positiivisen tulevaisuudenkuvan rakentamiseen (otsikkona RAISION UUDISTUMINEN KÄYNNISTYI). Retoriikan ja tuloksenhallinnan näkökulmista tappiota tekevä yhtiö pyrkii argumentoimaan tulevaisuuteen liittyvillä tiedoilla, koska historiatieto ei tue tasaisen kasvun toimintalogiikkaa. Retoriikan voi tulkita selviytymisretoriikaksi (toimitusjohtajan katsauksista vuosikertomuksissa, ks. Hermalahti 2003). Tulevaisuusperustelut ovat etualalla myös varsinaisessa toimintavuoden katsauksessa, jonka ensimmäinen väliotsikko on BioTien strategia. Tilinpäätöstiedote päättyy viestiin, joka selittää kirjoittajien valintoja:

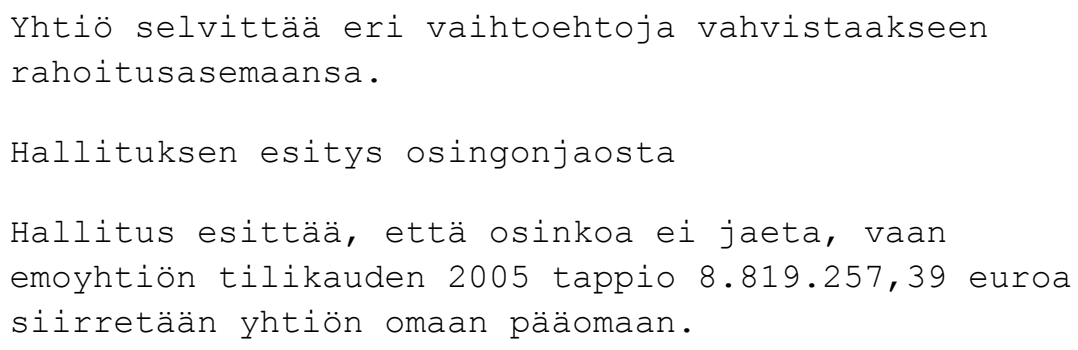

Myyvyyden ja profiloimisen näkökulmasta tiivistelmät ovat - toisin kuin otsikot - pääosin asenteettomia, ellei oteta huomioon positiivisten, mitattavaa kehitystä kuvaavien verbien käyttöä (kohota, nousta). Poikkeuksena ovat lehdistötiedotemaiset tilinpäätöstiedotteiden aloitukset (Raisio ja Neste Oil, ks. Liite 1). Tiivis kerronta tekee tekstistä objektiivisesti raportoivaa. Numerotietoja on paljon, mikä täydentää objektiivisuuden vaikutelmaa. Diskursiivisesti tulkittuna tekstiin, joka tiivistää yhtiön toi- 
mintavuoden numeroita käyttäen, on tulkittavissa tehokkuuden ja mittaamisen maailma, ehkä myös tietynlainen kilpailullisuuden ja rationaalisen päätöksenteon merkitys: yhtiöt kilpailevat sijoittajien rahoista. Raportointitapa on luonnollistunutta, eikä käsitteitä määritellä. Asiaa tuntemattomat rajataan näin tekstien ulkopuolelle.

Tilinpäätöstiedotteiden genreanalyysin päätulos on se, että tilinpäätöstiedote on eri tekstilajien piirteitä hyödyntävä hybriditeksti. Teksteissä on jälkiä lehdistötiedotteesta ja toimintakertomuksesta. Tyyli värittyy monilta osin markkinointihenkiseksi, mikä ilmentää tekstilajien piirteiden ja ammattikäytänteiden sekoittumista tilinpäätöstiedotteissa. Retoriikan näkökulmasta hybridiluonne tulee ilmi erityisesti lehdistötiedotetyylisestä tilinpäätöstiedotteesta (ks. Liite 1). Siinä missä neutraalisti tiedottavat tekstit pitäytyvät pääosin arvopaperipörssin sääntöjen mukaisessa tiedotuksessa, lehdistötiedotemainen kuvailee yhtiön toimintavuotta valikoiden teemoja niin, että yhtiö näyttäytyy positiivisessa valossa. Retorisena valintana pidän niin ikään esimerkiksi sitä, että osinkoehdotuksesta puhutaan monen sivun päässä aloitusjaksosta, jos yhtiön tulos on ollut yhtiön omien odotusten vastainen, vaikka positiivinen. Lehdistötiedotemainen kerronta kytkee tilinpäätöstiedotteen viestinnän ammattilaisen käytänteisiin: yhtiö pyritään esittämään mahdollisimman hyvässä valossa.

Tilinpäätöstiedote ei siis ole homogeeninen tekstilaji. Tiedotteiden rakenne vaihtelee, jopa siinä määrin, että yhtiöiden vertailu sijoitusmielessä on vaikeaa. Rakenteen löysä normitus Suomessa mahdollistaa siis tuloksenhallinnan tältä osin. Tulos on kiinnostava siksi, että kaiken pörssiyhtiön tiedottamisen sääntelyn ja ohjeistuksen tavoitteena on, että tilinpäätöstiedotteen lukija saa oikean kuvan yhtiöstä, mutta pystyy myös vertailemaan sijoituskohteita.

Tulosjulkistukseen liittyvä tuloksenhallinta sekä siihen kytkeytyvä suostuttelu ja profiloiminen ovat Suomessa kuitenkin maltillisempaa kuin Yhdysvalloissa (Graham ym. 2005). Tilinpäätöstiedotteen tekstilajien piirteet sekoittuvat lähinnä lehdistötiedotteen piirteisiin, mutta myös markkinointiviestintään: otsikkojen muotoilu, otsikkojen positiiviset sananvalinnat (esim. Neste Oil 2006, ks. Liite 1), tiivistelmän asiasisältöjen valinta ja negatiivisen tiedon sijoittaminen tilinpäätöstiedotteeseen. Tuloksenhallintaa ja profiloimista retoriikan keinoin on myös se, että tappiollinen yhtiö nostaa tekstin alkuun puhetta yhtiön strategiasta ja tulevaisuudesta samalla kun negatiivinen historiatieto siirretään taka-alalle (esim. Raisio). Tulokset ovat viime mainituilta osin Koljosen ja Heikkilän (2002) tutkimuksen tulosten mukaisia. Tilinpäätöstiedotteen tiukat sisältönormit siis säätelevät Suomessa viestintää aidosti sekä hillitsevät kielellistä ja diskursiivista tuloksenhallintaa, mutta ne eivät estä sitä täysin.

Kaiken kaikkiaan tilinpäätöstiedotteen mahdollisten valintojen varasto (Mäntynen 2006, 47-48) on suhteellisen suuri tekstilajin sisällön tiukasta sääntelystä huolimatta. Kontekstuaalisesti tilinpäätöstiedotteet ovat täysin yhtenäisiä: ne on kaikki tuotettu ja niitä oletetaan kulutettavan kaikkia samalla tavalla. Ammattikäytänteiden kannalta (Bhatia 2010) tutkimukseni osoittaa, että kokeneet päälistan pörssiyhtiöt ottavat vapauksia ja antavat viestinnän ammattikäytänteiden näkyä tekstissä. Uudet listautujat noudattavat selvemmin tiedottamisen sääntöjä, jolloin taloushallinto pääsee tekstissä ääneen. 


\section{Johtopäätökset}

Tekstilajin on aina oltava yhteisön jäsenten tunnistettavissa ja sen tulee hoitaa tehtävä, jota varten se on kirjoitettu. Velvoite liittyy myös tekstilajin vakauteen. Tekstintutkimukset ovat osoittaneet, että tekstilajit eivät voi kivettyä, vaan ne elävät yhteiskunnan käytänteiden muuttuessa (esim. Fairclough 2003; Bhatia 2004; Ridell 2006). Tekstilajin vakaus liittyy instituution valtasuhteisiin niin, että hierarkkisuus instituutiossa ja tekstilajiin liittyvä valvonta tekevät tekstilajista vakaan ja päinvastoin (Kress \& Threadgold 1988, sit. Solin 2006, 80). Vaihtelu ja luovuus liittyvät siis nimenomaan vapauteen. Tutkimukseni keskeinen päätelmä on, että vaihtelu suhteessa vakauteen tilinpäätöstiedotteessa on sellaista, että tilinpäätöstiedote on kyllä tunnistettavissa ja se hoitaa tulosjulkistuksen tehtävän, mutta lukijan on vaikea vertailla yhtiöitä sijoituskohteena tiedotteiden sekavan rakenteen vuoksi. Sen sijaan profiloimisen tarkoitusperät tulevat ilmi.

Tilinpäätöstiedotteissa kohtaavat normitettua talousviestintää hoitava taloushallinnon ammattilainen ja yhtiön profiloimista vaaliva viestinnän ammattilainen, tarkemmin sanottuna heidän ammattikäytänteensä ja kulttuurinsa. Käytänteiden ja kulttuurien sekoittaminen tekstissä on Bhatian mukaan taktista $(2010,27)$, mutta tekstilajiresurssien sekoittumisen pitäisi olla hallittua niin, että tekstilajin tunnistettavuus ja uskottavuus diskurssiyhteisössä eivät kärsi (Bhatia 2004, 114-115, 119, 151). Tilinpäätöstiedotteen uskottavuus sijoittajien silmissä ei tutkimukseni mukaan ole Suomessa uhattuna. Retorinen vaikuttaminen on tulkittavissa vakuuttamiseksi, ei niinkään suostuttelemiseksi: tarkistettavissa olevat tiedot ja numerot ovat keskeisessä roolissa yhtiön kehityksen kuvaamisessa. Äänessä on siis pääasiassa taloushallinnon ammattilainen.

Lisäksi profiloiminen on tilinpäätöstiedotteissa ilmeistä, ei verhottua, mikä voisi johtaa lukijaa harhaan (myös Henry 2008). Positiivisuusstrategiat näyttäytyvät uskottavuuden rakentamisena, esimerkkinä johdon sitaatti. Tällainen diskurssienvälisyys eli haastattelun tuominen kirjalliseen tekstiin on lukijan ja kirjoittajan suhdetta rakentava valinta, vaikka se voidaan kriittisesti tulkita näennäissiteeraukseksi, haastattelutilannetta jäljitteleväksi (Sleurs ym. 2003). Jos lehdistötiedotemainen tekstistrategia yleistyy, tulkitsen sen mukauttavan suomalaista tulosjulkistuskäytäntöä yhdysvaltalaiseen suuntaan.

Vaikka itse tilinpäätöstiedote näyttää objektiivisesti raportoivalta, otsikkoa hyödynnetään profiloinnin tarkoituksessa. Tämä on merkki siitä, että tiedotteen kohderyhmäksi on tulkittavissa myös media, joka välittää tietoa laajalle yleisölle. Tutkimukset kuitenkin osoittavat, että talousjournalistit seulovat tiedot myyvän aineksen joukosta oman kompetenssinsa pohjalta (esim. Pander Maat 2007, 90-91, 93; Luomaaho ym. 2011, 52) ja täydentävät tietoja tulkinnoin taustaorganisaationsa kulttuurin ja linjan pohjalta (Koljonen \& Heikkilä 2002, 96-100). Näyttää siltä, että erityisesti suuryrityksistä raportoidaan mediassa Suomessa faktuaalisesti, ja seurattava tarina on useimmiten toiminnan tulokseen liittyvä osakkeen hinnan kehitys pörssissä (Luomaaho ym. 2011, 50-51). Tulkitsenkin lopulta, että yhtiöiden vapaudet retorisissa valin- 
noissa suostuttelun suuntaan eivät Suomessa vaaranna tilinpäätöstiedotteen integriteettiä, kun tiedote nimetään tilinpäätöstiedotteeksi ja se sisältää hallituksen toimintakertomuksen ja tilinpäätöksen liitetietoineen, mikä toteutuu tutkituissa teksteissä. Sen sijaan tuloksenhallinnan tavoite näyttää selittävän vaihtelevan informaatiorakenteen (esimerkiksi vuonna 2005 tappiollisen Raision strategia-aiheinen aloitus). Suomi on pitkälti uskottavan ja faktapohjaisen tiedonvälityksen maa ja sellaiseksi jää, kuten Luoma-aho ja kumppanit päättelevät tutkimuksessaan (2011, 53).

Muutokset tekstin tuottamisen ja käyttämisen ympäristössä heijastuvat tekstilajiin. Tilinpäätöstiedotteen kontekstissa sijoittajayhteisö on muuttunut vuosikymmenten aikana. Suomessa merkittäviä historiallisia muutoksia tässä suhteessa ovat olleet 1980-1990-luvuilla rahoitusmarkkinoiden vapautuminen, sen myötä ulkomaalaisomistuksen lisääntyminen, Euroopan unionin sääntelyn mukaantulo ja vuosituhannen vaihteessa yksityissijoittajien kiinnostuksen kasvu erityisesti uusia listautujia kohtaan. Tietynlaisesta viestintäkulttuurin murroksesta viestii talouslehdistössä vuosituhannen vaihteessa käyty keskustelu pörssitiedottamisen liiallisesta markkinointihenkisyydestä. Media nosti aiheen agendalleen, kun NM-listan yhtiö Nedecon kertoi 6.9.1999 pörssitiedotteella, ei lehdistötiedotteella, uutisensa tiedotteen otsikossa näin:

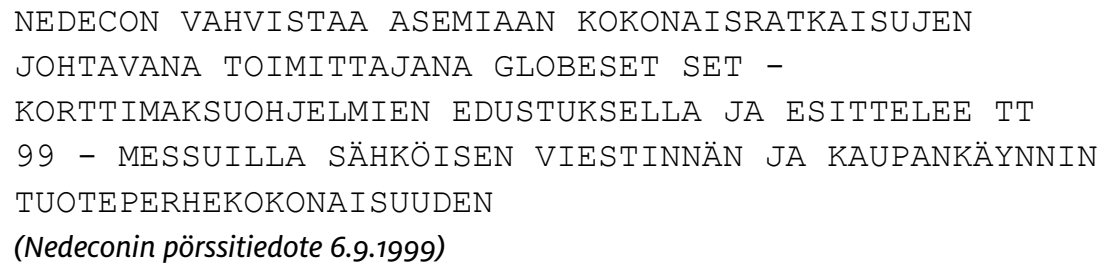

Toimittaja Kustaa Hulkko kysyi 8.9.1999 tiedotteeseen viitaten Kauppalehden palstalla Mistä on kysymys? (Hulkko 1999): "Onko pörssitiedote oikea paikka yhtiön omakehulle?" Mediassa käydyllä keskustelulla oli tervehdyttävä vaikutus tiedotuskäytäntöihin, ja Taloussanomat päätteli Helsingin pörssin johtajan Mika Björklundin lausuntojen pohjalta, että "kurssimanipulaatio näennäisuutisilla ei ole ongelma Helsingin pörssissä" (Ovaskainen 1999). Kulissien ylläpitämistä positiivisen uutisoinnin keinoin on sittemmin Suomessa hillinnyt muun muassa tiukentunut pörssitiedottamisen sääntely (Uskali 2005, 48).

Sijoittajaviestinnän käytännön työn kannalta on mahdollista ajatella, että tilinpäätöstiedottamisen ohjeita tarkistettaisiin tulkintaa haittaavan moniäänisyyden, tekstilajipiirteiden sekoittumisen ja rakenteen horjuvuuden vuoksi (tilinpäätöstiedotteen ohjeistamisesta myös Virtanen 2010, 273). Ikäheimo ja Mouritsen $(2007,67)$ suhtautuvat kuitenkin kriittisesti sijoittajaviestinnän ohjeiden tiukentamiseen. Heidän mukaansa naiivisti määriteltynä sijoittajaviestintä olisi tiedon puskemista markkinoille aina kun sitä on, ja vielä objektiivisesti ja neutraalisti. He vastustavat myös sitä luonnehdintaa, että sijoittajaviestintä olisi vain normeja noudattavaa numerotiedon esittämistä: "Kielen standardointi siistii yhtiön, ja samalla yhtiön todellisuuden rikkaus ei pääse esiin." (Emt., 67.) Yhdyn näkemykseen. Silti katson, että tekstilajien eri- 
koistuminen on sijoittajaviestinnässä luonnollista: toiset tekstit ovat objektiivisempia sijoittajaviestinnän välineitä (tilinpäätöstiedote), toiset taas retorisilta tarkoituksiltaan moninaisempia, esimerkiksi vuosikertomukset.

Sen sijaan viestinnän funktioiden sekoittuminen lukijan odotusten vastaisesti yhdessä ja samassa tekstissä aiheuttaa genrekonfliktin (Bhatia 2004), mikä pitemmän päälle murentaa yhtiön uskottavuutta ja mainetta. Ikäheimon ja Mouritsenin huoli siitä, että sijoittajaviestintä miellettäisiin pelkästään kuvailevaksi ja dokumentoivaksi funktioksi ilman sijoittajien houkuttelemista ja luottamuksen rakentamista, on turha. Sijoittajaviestinnän monia tehtäviä hoidetaan pitkälti myös kasvotusten, jolloin kirjallisella materiaalilla on paitsi dokumentoiva myös taustoittava funktio (myös Ikäheimo \& Mouritsen 2007, 68). Ikäheimon ja Mouritsenin näkemykseen yhtyen ja heitä lainaten totean, että kaikki sijoittajaviestinnän tarkoitukset ja tehtävät - tiedon asymmetrian vähentäminen, tiedonantovelvollisuuden täyttäminen, luottamuksen rakentaminen ja sijoittajien houkutteleminen - ovat kurinalaista sijoittajasuhdetoimintaa, jota kontrolloi keskitetty portinvartija.

Tutkimukseni teoreettisena antina on tutkittavan ilmiön, tuloksenhallinnan, monitieteisyyttä hyödyntävä genreanalyysi. Tutkimuksessa on nähtävissä ulkoisen yhteisöviestinnän (organizational and corporate communication) osa-alueen, sijoittajaviestinnän, kolmiulotteisuus: se on taloushallintoa, suhdetoimintaa sekä kielellistä ja diskursiivista toimintaa. Genreanalyysi, joka hyödyntää tekstin konteksteja laajasti sekä tekstin mikro- ja makrotason analyysia, on tarkempi ja kattavampi kuin monet muut menetelmät ja antaa perusteltuja tulkintoja tekstin merkityksistä (Bhatia 2010, 37). Menetelmän heikkoutena voi pitää sitä, että se on työläs: kielen ja tyylin analyysi ei mahdollista suuria aineistoja (myös Jokinen 1999, 43). Tutkimus on kuitenkin merkityksellistä tulosten siirrettävyyden vuoksi (Kakkuri-Knuuttila \& Heinlahti 2006, 175): yleisten säännönmukaisuuksien sijaan tutkimus tuo esiin talouselämän yksityiskohtia, joita on analysoitu yleisempien käsitteiden avulla ja joiden merkitystä lukija voi arvioida muissa tapauksissa. Tutkimus avaa monia jatkotutkimusaiheita: Sijoittajaviestinnän monitieteistä tutkimusta voi laajentaa siihen, mikä merkitys eri tekstilajeilla on pörssiyhtiön strategisessa johtamisessa. Päiväjärjestysmallin (agenda-setting theory, Luoma-aho ym. 2011, 39) näkökulmasta puolestaan talousmedian pörssiuutisointia voisi tutkia monin menetelmin ja aineistoin. Samoin kiinnostavaa olisi tutkia, miten talouskriisit vaikuttavat pörssiyhtiöiden viestintään ja maineenhallintaan: miten perustella sijoittajalle valoisaa tulevaisuutta - ja sijoitukselle tuottoa - kun näkymä on sumea ja lyhyt, ehkä vain yhden kvartaalin mittainen. 


\section{Viitteet}

1 The National Investor Relations Institute, NIRI

2 Suomennos artikkelin kirjoittajan.

3 Suomessa on sijoittajaviestinnän tutkimusta tehty vain vähän. Siksi käytän Helsingin kauppakorkeakoulussa tehtyjä pro gradu -tutkimuksia lähteinä. Valitsemissani lähteissä tutkimusasetelma on ollut luotettava ja tutkimukset antavat tärkeää tietoa talousviestinnästä; esimerkiksi Kuningas (2004).

$4 \quad$ Terminä englannissa on Earnings Press Release, joka vastaa osavuosikatsausta Suomessa. Tilinpäätöstiedote on esimerkiksi Financial Statement Press Release.

$5 \quad$ New Market -lista oli Helsingin pörssissä käytössä syksyyn 2006 saakka.

6 Vuonna 2006 toimialaluokitus oli tietyiltä osin poikkeava vuoden 2012 luokituksesta.

7 Aineisto on tekstianalyysille tyypillisen kokoinen (tässä 27 yhtiön tekstit, jotka voivat kokonaisuudessaan olla kymmenien sivujen mittaisia; esimerkiksi Crawford Camiciottolilla 20 tulosjulkistuspuhelua analyytikoille, 2010). Juhila ja Suoninen $(1999,241)$ ovat todenneet, että diskurssianalyysin ilmeinen varjopuoli on aineiston analyysin työläys ja että täsmällistä rajaa riittävälle aineiston koolle on vaikea asettaa. Aineiston valintaa ohjaa diskurssintutkimuksessa tutkimusintressi (emt.), joka tässä työssä on tuloksenhallintaan liittyvät kielelliset ja diskursiiviset käytännöt Suomessa.

8 Metateksti on tekstiä tekstistä. Esimerkiksi lausuma "seuraavaksi tarkastellaan x:ää" on tekstissä eteenpäin viittaava metateksti, lausuma "tässä kohdin on tärkeää huomata -" puolestaan on kirjoittajan suhtautumista asiaan osoittavaa interpersoonaista metatekstiä. Metatekstiä voidaan käyttää jäsentämään tekstiä ja opastamaan lukijaa.

\section{Kirjallisuus}

Beattie, Vivien \& Dhanani, Alpa \& Jones, Michael (2008). Investigating presentational change in U.K. annual reports: a longitudinal perspective. Journal of Business Communication 45: 2, 181- 222.

Bex, Tony (1996). Variety in written English: Texts in society: Societies in text. London: Routledge.

Bhatia, Vijay K. (2010). Interdiscursivity in professional communication. Discourse Q communication 21: 1, 32-50.

Bhatia, Vijay K. (2004). Worlds of written discourse: A general-based view. London and New York: Continuum.

Bhatia, Vijay K. (1993). Analysing genre: Language use in professional settings. London: Longman.

Carroll, Craig E. (2011). International perspectives on agenda-setting theory applied to business news. Teoksessa: Carroll, Craig E. (toim.). Corporate reputation and the news media. New York and London: Routledge.

Chouliaraki, Lilie \& Fairclough, Norman (2010). Critical discourse analysis in organizational studies: Towards an integrationist methodology. Journal of management studies 47: 6, 1213-1218.

Cole, Benjamin Mark (toim.) (2004). The new investor relations: expert perspectives on the state of the art. Princeton, NJ: Bloomberg Press.

Crawford Camiciottoli, Belinda (2010). Earnings calls: Exploring an emerging financial reporting genre. Discourse Q communication 4: 4, 343-359.

Degeorge, Francois; Patel, Jayendu \& Zeckhauser, Richard (1999). Earnings management to exceed thresholds. Journal of business 72: 1, 1-33.

Eggins, Susan \& Martin, Jim R. (1997). Genres and registers of discourse. Teoksessa: van Dijk, Teun A. (toim.). Discourse as structure and process: Discourse studies: a multidisciplinary introduction. London: SAGE, 230-256.

Fairclough, Norman (2003). Analysing discourse: textual analysis for social research. London and New York: Routledge.

Fairclough, Norman (1992). Discourse and social change. London: Polity press.

Finanssivalvonta (2010). Selvitys listayhtiöiden taloudellisista raporteista. Markkinat 2010: 1. Helsinki: Finanssivalvonta.

Finanssivalvonta (2009a). Säännöllinen tiedonantovelvollisuus. Tietojen julkistamisen standardit 5.1. Saatavilla: http://www.finanssivalvonta.fi/fi/Saantely/Maarayskokoelma/Rahoitussektori/5_ Tietojen_julkistaminen/Documents/5.1.std2.pdf (luettu 7.1.2010). 
Finanssivalvonta (2009b). Liikkeeseenlaskijan ja osakkeenomistajan tiedonantovelvollisuus. Tietojen julkistamisen standardit 5.2b. Saatavilla: http://www.finanssivalvonta.fi/fi/Saantely/ Maarayskokoelma/Rahoitussektori/5_Tietojen_julkistaminen/Documents/5.2b.std2.pdf (luettu 7.1.2010).

Graham, John R.; Harvey, Campbell R. \& Rajgopal, Shiva (2005). The economic implications of corporate financial reporting. Journal of accounting and economics 40: 1-3, 3-73.

Hallaghan, Kirk; Holtzhausen, Derina; van Ruler, Betteke; Vercic, Dejan \& Sriramesh, Krishnamurthy (2007). Defining strategic communication. International journal of strategic communication 1: 1, 3-35.

Halliday, M.A.K. (1994). An introduction to functional grammar. London: Arnold.

Hasan, Raqaiya (1989 [1985]). The structure of a text. Teoksessa: Halliday, M.A.K. \& Hasan, Raqaiya (toim.). Language, context and text: Aspects of language in a social-semiotic perspective. Oxford: Oxford University Press, 52-69.

Heikkinen, Vesa (2004). Jauhelihaa ja muita konteksteja. Kulttuurintutkimus 21: 2, 23-34.

Henry, Elaine (2008). Are investors influenced by how earnings press releases are written? Journal of business communication 45: 4, 363-407.

Hens, Thorsten (2008). The earnings game with behavioral investors. Working paper. March 3, 2008. Saatavilla: http://papers.ssrn.com/sol3/papers.cfm?abstract_id=1101505 (luettu 22.4.2010).

Hermalahti, Susanna (2003). Kerronta, aika ja argumentaatio: toimitusjohtajan katsaus vuosikertomuksen osana. Pro gradu -tutkielma. Helsingin kauppakorkeakoulu, suomen kieli ja viestintä. Helsinki: HeSE Print.

Hirsto, Heidi \& Moisander, Johanna (2010). Restructuring responsibility: globalist articulations of business-society relations. Teoksessa: Hirsto, Heidi. Vastuutonta puhetta: esseitä talouden merkityksellistämisestä. Aalto-yliopiston kauppakorkeakoulu, A-377. Helsinki: Aalto Print.

Hulkko, Kustaa (1999). Mistä on kysymys?: Onko pörssitiedote oikea paikka yhtiön omakehulle? Kauppalehti 8.9.1999.

Ikäheimo, Seppo \& Mouritsen, Jan (2007). Investor relations and the production of fair values and market values. Teoksessa: Granlund, Markus (toim.). Total quality in academic accounting: Essays in honour of Kari Lukka. Sarja C 3: 2007. Turku: Turun kauppakorkeakoulu, 63-79.

Ikävalko, Elisa (1996). Ylivoimapeli mediassa. Julkisuusmekanismit ja julkisuuden hallinta. Helsinki: Inforviestintä.

Internet-pörssitiedote (1999). Helsingin arvopaperipörssin ohje. 18.5.1999. Helsinki: Helsingin Pörssi.

Jokinen, Arja (1999). Diskurssianalyysin suhde sukulaistraditioihin. Teoksessa: Jokinen, Arja; Juhila, Kirsi \& Suoninen, Eero (toim.). Diskurssianalyysi liikkeessä. Tampere: Vastapaino, 37-53.

Juhila, Kirsi \& Suoninen, Eero (1999). Kymmenen kysymystä diskurssianalyysista. Teoksessa: Jokinen, Arja; Juhila, Kirsi \& Suoninen, Eero (toim.). Diskurssianalyysi liikkeessä. Tampere: Vastapaino, 233-252.

Juholin, Elisa (2009). Communicare! Viestintä strategiasta käytäntöön. 5. uudistettu painos. Helsinki: Infor.

Kakkuri-Knuuttila, Marja-Liisa \& Heinlahti, Kaisa (2006). Mitä on tutkimus? Argumentaatio ja tieteenfilosofia. Helsinki: Gaudeamus.

Kakkuri-Knuuttila, Marja-Liisa (toim.) (1998). Argumentti ja kritiikki: lukemisen, keskustelun ja vakuuttamisen taidot. Helsinki: Gaudeamus.

Kariola, Raija; Angervuo, Hannu \& Niemelä, Jaakko E. (2004). Yritys sijoittajamarkkinoilla: sijoittajasuhdetoiminnan haasteet ja mahdollisuudet. Helsinki: WSOY.

Kasanen, Eero; Kinnunen, Juha \& Niskanen, Jyrki (1996). Dividend-based earnings management: Empirical evidence from Finland. Journal of Accounting and Economics 22, 283-312.

Koljonen, Kari \& Heikkilä, Heikki (2002). Taru yrityksen herrasta: Elcoteq ja talousjulkisuuden suhdanteet vuosina 1997-2001. Tampere: Journalismin tutkimusyksikkö, Tampereen yliopisto.

Kress, Gunter \& Threadgold, Terry (1988). Towards a social theory of genre. Southern Review 21, 215-243.

Kunelius, Risto (1996). The news, textually speaking: Writing on news journalism and journalism research. Tampere: University of Tampere.

Kuningas, Solja (2004). Tulostiedotteiden tuottamat juttutyypit. ICT-yhtiöiden tilinpäätökset mediassa 20022003. Pro gradu -tutkielma. Helsingin kauppakorkeakoulu, suomen kieli ja viestintä. Helsinki: HeSE Print.

Lassen, Inger (2006). Is the press release a genre: A study of form and content. Discourse studies 8: 4, 503-530. 
Luoma-aho, Vilma; Uskali, Turo; Heinonen, Jouni \& Ainamo, Antti (2011). Corporate reputation and the news media in Finland. Teoksessa: Carroll, Craig E. (toim.). Corporate reputation and the news media. New York and London: Routledge.

Majapuro, Marketta (2006). Talousjournalismi: historiaa, teoriaa, käytäntöä. Helsingin kauppakorkeakoulun julkaisuja. Helsinki: HeSE Print.

Manning, Paul (2001). News and news source: a critical introduction. London: SAGE.

Martin, Jim R. \& Rose, David (2003). Working with discourse: Meaning beyond the clause. Open linguistics series. London: Continuum.

Mauranen, Anna (1993). Cultural differences in academic rhetoric: A textlinguistic study. Frankfurt am Main: Peter Lang.

Mäntynen, Anne (2006). Näkökulmia tekstin ja tekstilajin rakenteeseen. Teoksessa: Mäntynen, Anne; Shore, Susanna \& Solin, Anna (toim.). Genre - tekstilaji. Helsinki: Suomalaisen Kirjallisuuden Seura, 42-71.

Mäntynen, Anne \& Shore, Susanna (2006). Tekstilajien risteyksessä: Mika Myllylän testamentti. Teoksessa: Mäntynen, Anne; Shore, Susanna \& Solin, Anna (toim.). Genre - tekstilaji. Helsinki: Suomalaisen Kirjallisuuden Seura, 283-302.

Ovaskainen, Kai (1999). Tukholman pörssi otti uudet IT-yritykset erityistarkkailuun. Kurssimanipulaatio näennäisuutisilla ei ole ongelma Helsingin pörssissä. Taloussanomat 18.9.1999.

Pander Maat, Henk (2007). How promotional language in press releases is dealt with by journalists. Journal of business communication 44: 1, 59-95.

Perelman, Chaïm (1996 [1977]). Retoriikan valtakunta. Tampere: Vastapaino.

Perelman, Chaïm \& Olbrechts-Tyteca, Lucie (1971). The new rhetoric: A treatise on argumentation. Notre Dame: University of Notre Dame press.

Pietikäinen, Sari \& Mäntynen, Anne (2009). Kurssi kohti diskurssia. Tampere: Vastapaino.

Ridell, Seija (2006). Genre ja mediatutkimus. Teoksessa: Mäntynen, Anne; Shore, Susanna \& Solin, Anna (toim.). Genre - tekstilaji. Helsinki: Suomalaisen Kirjallisuuden Seura, 184-213.

Seetharaman, Arumugam \& Subramanian, Ramaiyer (2005). Navigating the web of financial reporting. European Business Forum:Europe's perspective on global management issues 23: 6, 51-54.

Sleurs, Kim; Jakobs, Geert \& Van Waes, Luuk (2003). Constructing press releases, constructing quotations: A case study. Journal of Sociolinguistics $7: 2,192-212$.

Solin, Anna (2006). Genre ja intertekstuaalisuus. Teoksessa: Mäntynen, Anne; Shore, Susanna \& Solin, Anna (toim.). Genre - tekstilaji. Helsinki: Suomalaisen Kirjallisuuden Seura, 72-95.

Sundgren, Stefan (2007). Earnings management in public and private companies: evidence from Finland. Liiketaloudellinen aikakauskirja 1, 35-63.

Swales, John (1990). Genre analysis: English in academic settings. Cambridge: Cambridge university press.

Uskali, Turo (2005). Talousjournalismin historia, rajat ja tulevaisuus. Teoksessa: Ojala, Jari \& Uskali, Turo (toim.). Mediajättien aika. Helsinki: Inforviestintä, 27-54.

Vehmanen, Petri (2002). Tilinpäätösinformaation ennustepitoisuus. Liiketaloudellinen aikakauskirja 2, 208215.

Ventola, Eija (2006). Genre systeeemis-funktionaalisessa kielitieteessä. Esimerkkinä asointitilanteet. Teoksessa: Mäntynen, Anne; Shore, Susanna \& Solin, Anna (toim.). Genre - tekstilaji. Helsinki: Suomalaisen Kirjallisuuden Seura, 96-121.

Verdonk, Peter (2002). Stylistics. Oxford: Oxford University Press.

Virtanen, Marjatta (2010). Sijoittajasuhteet johdon vastuuna. Helsinki: WSOY.

Werlich, Egon (1976). A text grammer of English. Universitätstaschenbuch 597. Heidelberg: Quelle \& Meyer. 

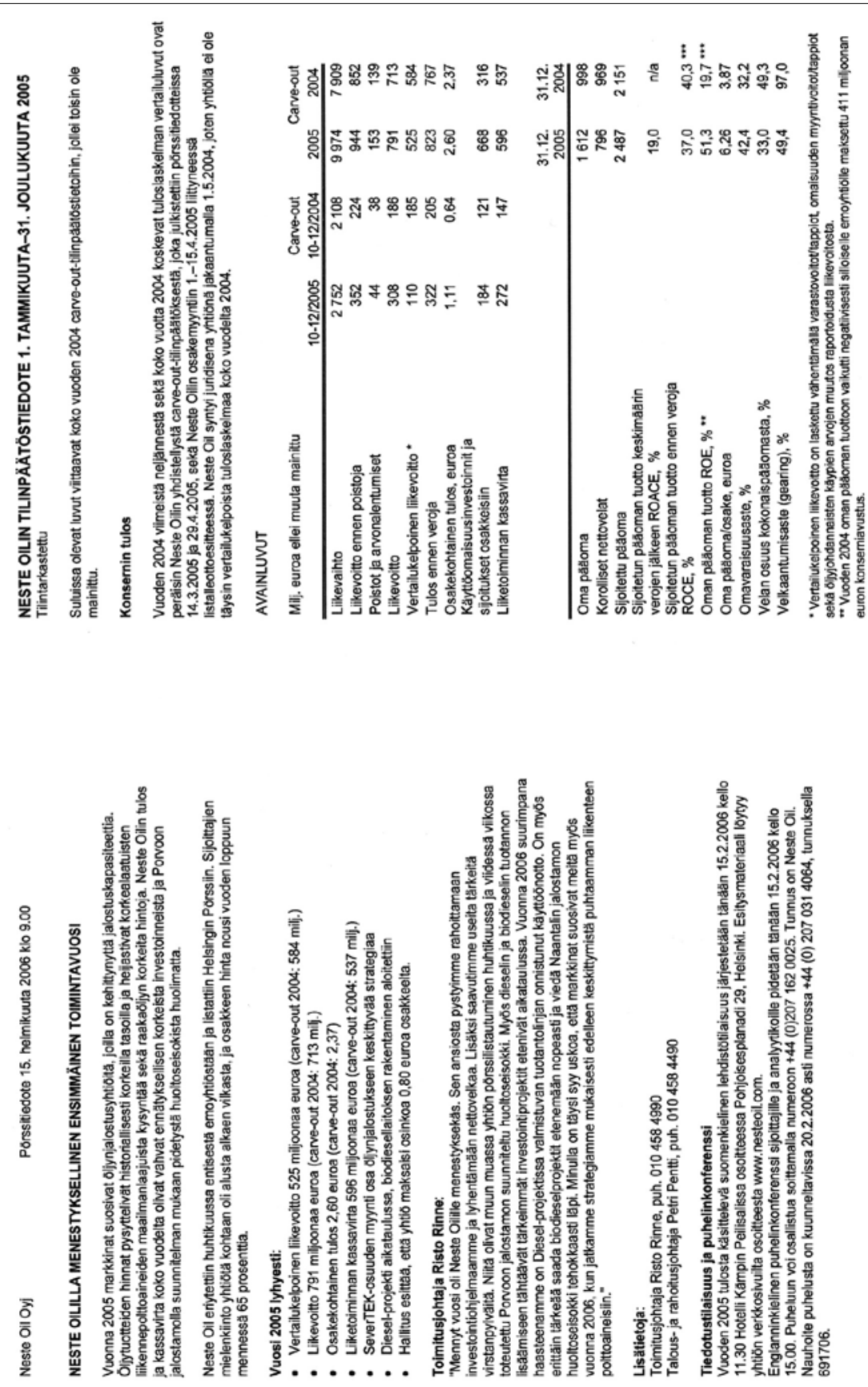

Liite 1: Neste Oilin tilinpäätöstiedote, 15.2.2006 